\title{
STK11 Gene Mutation
}

National Cancer Institute

\section{Source}

National Cancer Institute. STK11 Gene Mutation. NCI Thesaurus. Code C128825.

A change in the nucleotide sequence of the ST K11 gene. 